\title{
Angka Kejadian Hipotermia dan Lama Perawatan di Ruang Pemulihan pada Pasien Geriatri Pascaoperasi Elektif Bulan Oktober 2011-Maret 2012 di Rumah Sakit Dr. Hasan Sadikin Bandung
}

\author{
Anggita Marissa Harahap, ${ }^{1}$ Rudi K. Kadarsah, ${ }^{2}$ Ezra Oktaliansah ${ }^{2}$ \\ ${ }^{1}$ Kamar Operasi dan ICU Siloam Hospital Lippo Cikarang, \\ ${ }^{2}$ Departemen Anestesiologi dan Terapi Intensif \\ Fakultas Kedokteran Universitas Padjadjaran/Rumah Sakit Dr. Hasan Sadikin Bandung
}

\begin{abstract}
Abstrak
Tindakan anestesi dan pembedahan adalah salah satu penyebab kejadian hipotermia. Keadaan ini sangat tidak menguntungkan bagi pasien geriatri dengan gangguan fungsi kardiopulmonal. Penelitian dilakukan dengan metode prospektif observasional dengan rancangan penelitian deskriptif kasus kontrol terhadap 129 orang pasien geriatri pascaanestesi umum dan pascaanestesi regional yang masuk ke ruang pemulihan Rumah Sakit Dr. Hasan Sadikin Bandung pada Oktober 2011 sampai Maret 2012. Angka kejadian hipotermia pada pasien geriatri pascaanestesi di ruang pemulihan sebanyak 113 orang $(87,6 \%)$. Terdapat hubungan bermakna kejadian hipotermia dengan lama perawatan di ruang pemulihan pada pasien geriatri yang telah menjalani operasi elektif di Rumah Sakit Dr. Hasan Sadikin Bandung ( $\leq \leq 0,05)$. Lama tinggal di ruang pemulihan rata-rata pada pasien hipotermia adalah 110 menit dan pada pasien yang tidak hipotermia 70 menit. Simpulan penelitian ini menunjukkan bahwa angka kejadian hipotermia pascaoperatif geriatri adalah $87,6 \%$ dan pasien dengan hipotermia mendapatkan perawatan lebih lama di ruang pemulihan.
\end{abstract}

Kata kunci: Hipotermia pascaanestesi, lama perawatan, geriatri, ruang pemulihan

\section{The Incidence of Hypothermia and Duration of Care in the Recovery Room on Postoperative Geriatric Patients at Dr. Hasan Sadikin Hospital Bandung During October 2011-March 2012}

\begin{abstract}
Anesthesia and surgery is one of the causes of the incidence of hypothermia. This situation is not favorable for geriatric patients with impaired cardiopulmonary function. This was a prospective observational study with a descriptive case-control design on 129 geriatric patients post general and regional anaesthesia in the recovery room of Dr. Hasan Sadikin Hospital Bandung during the period of October 2011 to March 2012. The incidence of hypothermia in geriatric patients post anaesthesia in recovery room was 113 people (87.6\%). There was a significant relationship between the incidence of hypothermia and the duration of care in the recovery room in geriatric patients who have undergone elective surgery at the Dr. Hasan Sadikin Hospital Bandung $(p \leq 0.05)$. Average the length of stay in recovery room was 110 minutes in patients experiencing hypothermia while it was 70 minutes in those whom did not experience hypothermia. In conclusions, the incidence of postoperative hypothermia in geriatric patients was $87.6 \%$ and patients whom experienced hypothermia have a longer care in the recovery room.
\end{abstract}

Key words: Geriatric, hypothermia post anesthesia, length of stay

Korespondensi: Anggita Marissa Harahap, dr., SpAn, Kamar Operasi dan ICU Siloam Hospital Lippo Cikarang, Jl. M.H. Thamrin Kav. 105 Lippo Cikarang, Bekasi 17550, Telp/Faks 021-89901088 Ext. 2705/0218972470, Mobile 0811646795082121157027 Email anggitasiloam@gmail.com 


\section{Pendahuluan}

Hipotermia adalah komplikasi pascaanestesi yang sering ditemukan di ruang pemulihan, baik pascaanestesi umum maupun regional. Hipotermia ialah keadaan dengan temperatur inti $1^{\circ} \mathrm{C}$ lebih rendah di bawah temperatur ratarata inti tubuh manusia pada keadaan istirahat dengan suhu lingkungan yang normal. Satu dari tiga pasien akan mengalami hipotermia selama operasi bila tidak dilakukan intervensi. Sekitar 30 sampai $40 \%$ pasien pascaanestesi ditemukan dalam keadaan hipotermia ketika tiba di ruang pemulihan. Bila suhu kurang dari $36{ }^{\circ} \mathrm{C}$ dipakai sebagai patokan, maka insidensi hipotermia ialah sebesar 50-70\% dari seluruh pasien yang menjalani operasi. ${ }^{1-3}$

Beberapa penelitian telah membuktikan dampak negatif hipotermia terhadap pasien, antara lain ialah risiko perdarahan meningkat, iskemia miokardium, pemulihan pascaanestesi yang lebih lama, gangguan penyembuhan luka, serta meningkatnya risiko infeksi. Hipotermia akan menambah kebutuhan oksigen, produksi karbon dioksida, dan juga peningkatan kadar katekolamin di dalam plasma yang akan diikuti dengan peningkatan laju nadi, tekanan darah, serta curah jantung. Keadaan ini sangat tidak menguntungkan bagi pasien, terutama pasien geriatri yang telah mengalami penurunan bahkan gangguan pada fungsi kardiovaskular dan juga pulmonal (seperti hipertensi, aritmia jantung, gagal jantung, dan infark miokardium). Pada pasien geriatri telah terjadi penurunan kemampuan untuk meningkatkan laju jantung dalam merespons kondisi hipoksia, hipotensi, dan hipovolemia. Peregangan paru dan fungsi tubular ginjal juga telah terjadi penurunan. ${ }^{1,}$ 4-10

Kombinasi antara gangguan termoregulasi yang diakibatkan oleh tindakan anestesi dan paparan suhu lingkungan yang rendah, akan mengakibatkan hipotermia pada pasien yang mengalami pembedahan. Dalam 1 jam pertama anestesi dapat terjadi penurunan suhu tubuh sebesar 0,5 sampai $1,5^{\circ} \mathrm{C}$. Secara garis besar mekanisme penurunan suhu selama anestesi, melalui 1.) Kehilangan panas pada kulit oleh karena proses radiasi, konveksi, konduksi, dan juga evaporasi, yang lebih lanjut menyebabkan redistribusi panas dari inti tubuh ke perifer, 2.) Produksi panas tubuh yang menurun oleh karena penurunan laju metabolisme. ${ }^{11-12}$

Pasien geriatri termasuk ke dalam golongan usia yang ekstrem, sehingga merupakan risiko tinggi untuk terjadi hipotermia pada periode perioperatif. Anestesia umum yang dilakukan pada pasien usia geriatri dapat menyebabkan pergeseran pada ambang batas termoregulasi dengan derajat yang lebih besar dibandingkan dengan pasien yang berusia muda. Golongan usia geriatri merupakan faktor risiko urutan 6 (enam) besar sebagai penyebab hipotermia perioperatif. ${ }^{13}$ Populasi geriatri akan semakin meningkat dan diperkirakan pada tahun 2040 masyarakat usia 65 tahun ke atas berjumlah $24 \%$ dari seluruh populasi penduduk, dengan demikian pasien geriatri yang membutuhkan tindakan bedah juga akan meningkat. ${ }^{14}$ Data Instalasi Bedah Sentral Rumah Sakit Dr. Hasan Sadikin Bandung tahun 2010 tercatat sebanyak 1.267 pasien geriatri menjalani pembedahan elektif.11

Kejadian hipotermia pada pasien geriatri disebabkan perubahan fungsi kardiovaskular (kekakuan pada area dinding pembuluh darah arteri, peningkatan tahanan pembuluh darah perifer, dan juga penurunan curah jantung), kekakuan organ paru dan kelemahan otot-otot pernapasan mengakibatkan ventilasi, difusi, serta oksigenasi tidak efektif. Selain itu, pada geriatri terjadi perubahan fungsi metabolik, seperti peningkatan sensitivitas pada reseptor insulin periferal, dan juga penurunan respons adrenokortikotropik terhadap faktor respons stres. . $, 9,10,15$

Hipotermia yang terjadi pada perioperatif dapat berlanjut hingga periode pascaoperatif di ruang pemulihan. Hipotermia yang terjadi saat pasien di ruang pemulihan harus secepatcepatnya dilakukan tindakan intervensi untuk mengatasi keadaan tersebut. Penatalaksanaan hipotermia yang dapat dikerjakan meliputi tindakan nonfarmakologis serta farmakologis. Teknik terapi nonfarmakologis dapatdilakukan dengan pencegahan proses redistribusi yang menyebabkan hipotermia, antara lain dengan pemberian selimut hangat. Redistribusi panas 
terjadi saat vasodilatasi yang disebabkan oleh tindakan anestesia, sehingga panas berpindah dari inti tubuh ke perifer. Teknik penghangatan seluruh permukaan tubuh secara pre-emptive dapat dilakukan dengan menggunakan forced air warming. Alat penghangat pasif termasuk menggunakan kain katun dapat dipergunakan untuk mengurangi pelepasan panas tubuh ke lingkungan. ${ }^{11,12}$

Tujuan penelitian ini untuk memperoleh gambaran besarnya angka kejadian hipotermia pada pasien geriatri yang menjalani operasi elektif saat di ruang pemulihan Rumah Sakit Dr. Hasan Sadikin Bandung dan memperoleh gambaran lama perawatan di ruang pemulihan apabila terjadi hipotermia pada pasien geriatri.

\section{Subjek dan metode}

Subjek penelitian ialah pasien geriatri di ruang pemulihan Rumah Sakit Dr. Hasan Sadikin Bandung yang telah selesai menjalani tindakan operasi elektif serta telah memenuhi kriteria inklusi dan tidak termasuk kriteria eksklusi. Kriteria inklusi, adalah pasien usia $\geq 65$ tahun dan juga pasien normotermia saat preoperatif. Kriteria eksklusi adalah pasien geriatri yang sedang mendapat terapi antipiretik, hipotiroid, hipertiroid, serta memiliki gangguan sistemik berat (status fisik ASA IV).

Pengumpulan sampel penelitian dilakukan selama 6 bulan, dimulai bulan Oktober 2011 sampai dengan Maret 2012 terhadap seluruh pasien geriatri yang masuk ke ruang pemulihan pascaoperasi elektif dengan anestesia umum maupun anestesia regional di Rumah Sakit Dr. Hasan Sadikin Bandung.

Jenis penelitian ialah observasional dengan rancangan penelitian bersifat cross sectional yang dilakukan dengan cara deskriptif melalui pengukuran yang dilakukan secara bersamaan terhadap 2 variabel, yaitu hipotermia dan juga lama perawatan.

Analisis data pada penelitian ini merupakan suatu analisis deskriptif yang menggambarkan kejadian hipotermia pada pasien geriatri dalam bentuk jumlah dan juga persentase, sedangkan untuk lamanya perawatan di ruang pemulihan dipergunakan nilai rata-rata, simpangan baku/ deviasi standar (SD), median, nilai minimal, dan juga maksimal. Analisis data dilakukan menggunakan program statistical product and servise solution (SPSS) for windows versi 17.0.

Setelah mendapat surat persetujuan/izin dari Komite Etik Penelitian Kesehatan Rumah Sakit Dr. Hasan Sadikin/Fakultas Kedokteran Universitas Padjadjaran, pasien/subjek yang telah sesuai dengan kriteria inklusi diberikan penjelasantentang proseduryangakan dijalani, kemudian menandatangani surat persetujuan (informed consent). Pasien geriatri yang masuk ke ruang pemulihan diukur temperatur tubuh, kemudian dilakukan pemasangan alat pantau tekanan darah noninvasif, elektrokardiografi (EKG), dan juga pulse oksimetri, dilanjutkan pengukuran tekanan darah sistol, diastol, laju nadi, dan saturasi oksigen. Pengukuran suhu tubuh, tekanan darah, laju nadi, dan saturasi

Tabel 1 Nilai Rata-rata dan Simpangan Baku Karakteristik Subjek Penelitian pada Pasien Geriatri

\begin{tabular}{lcccc}
\hline \multicolumn{1}{c}{ Karakteristik Subjek } & $\mathbf{n ~ ( \% )}$ & Rata-rata (SB) & Median & Rentang \\
\hline Usia (tahun) & & $70,63(4,96)$ & 69 & $65-86$ \\
Jenis kelamin & & & \\
$\quad$ Laki-laki & $63(48,8 \%)$ & & & \\
Perempuan & $66(51,2 \%)$ & & & \\
Indeks massa tubuh $\left(\mathrm{kg} / \mathrm{m}^{2}\right)$ & & $22,60(1,64)$ & 22,6 & $17,58-6,04$ \\
Lama operasi (menit) & & $199,88(83,35)$ & 180 & $70-495$ \\
Suhu ruang operasi $\left({ }^{\circ} \mathrm{C}\right)$ & & $23,73(0,64)$ & 24 & $23-25$ \\
Lama puasa $(j a m)$ & $8,80(2,08)$ & 8 & $6-14$ \\
\hline
\end{tabular}


Tabel 2 Kejadian Hipotermia dan Suhu Tubuh Saat Masuk Ruang Pemulihan

\begin{tabular}{lcccc}
\hline \multicolumn{1}{c}{ Variabel } & n (\%) & Rata-rata (SB) & Median & Rentang \\
\hline Kejadian hipotermia & & & & \\
Ya & $113(87,6 \%)$ & & & \\
Tidak & $16(12,4 \%)$ & & 35,7 & $35,3-36,1$ \\
$\begin{array}{l}\text { Suhu tubuh saat masuk ruang } \\
\text { pemulihan }\left({ }^{\circ} \mathrm{C}\right)\end{array}$ & & $35,7(0,19)$ & 35,7 \\
\hline
\end{tabular}

oksigen yang diukur tiap 10 menit, mulai saat pasien masuk ruang pemulihan sampai pasien dapat dipindahkan ke ruang perawatan sesuai dengan penilaian Modified Aldret Score. Bila terjadi hipotermia maka dilakukan pemberian selimut penghangat, lampu penghangat, serta cairan hangat sampai tercapainya suhu tubuh normotermia. Setelah keadaan normotermia, serta penilaian Modified Aldret Score $\geq 9$ maka pasien dipindahkan ke ruang perawatan.

\section{Hasil}

Pada penelitian ini karakteristik usia rata-rata pasien ialah 70,63 tahun dengan rentang usia 65-86 tahun. Jenis kelamin perempuan lebih banyak apabila dibandingkan dengan laki-laki, yaitu $51,2 \%$. Indeks massa tubuh (IMT) ratarata pasien adalah $22,60 \mathrm{~kg} / \mathrm{m}^{2}$, dengan indeks massa tubuh paling rendah $17,58 \mathrm{~kg} / \mathrm{m}^{2}$ serta indeks massa tubuh paling besar $26,04 \mathrm{~kg} / \mathrm{m}^{2}$
(Tabel 1).

Lama operasi rata-rata ialah 199,88 menit dengan durasi tindakan operasi paling cepat 70 menit dan paling lama adalah 495 menit. Suhu ruang operasi rata-rata adalah $23,73{ }^{\circ} \mathrm{C}$. Selanjutnya, lama puasa rata-rata adalah 8,8 jam dengan lama puasa paling cepat 6 jam dan puasa paling lama 14 jam.

Angka kejadian hipotermia saat pasien di ruang pemulihan sebanyak 113 orang $(87,6 \%)$ dengan suhu tubuh rata-rata saat masuk ruang pemulihan $35,7{ }^{\circ} \mathrm{C}$, median $35,7^{\circ} \mathrm{C}$, suhu tubuh paling rendah $35,3{ }^{\circ} \mathrm{C}$, suhu tubuh paling tinggi $36,1^{\circ} \mathrm{C}$ (Tabel 2).

Hasil uji statistika menggunakan Uji MannWhitney dengan nilai uji kepercayaan sebesar 95\% menunjukkan bahwa terdapat hubungan yang bermakna antara lama tindakan operasi dan kejadian hipotermia di ruang pemulihan $(p \leq 0,05)$. Pada penelitian ini juga didapatkan perbedaan bermakna laki-laki dan perempuan

Tabel 3 Hubungan Karakteristik Umum Subjek Penelitian dengan Kejadian Hipotermia di Ruang Pemulihan

\begin{tabular}{|c|c|c|c|c|c|c|c|}
\hline \multirow{3}{*}{ Variabel } & \multicolumn{6}{|c|}{ Kejadian hipotermia } & \multirow{3}{*}{ Nilai p } \\
\hline & \multicolumn{3}{|c|}{ Ya } & \multicolumn{3}{|c|}{ Tidak } & \\
\hline & n (\%) & Rata-rata & SB & n (\%) & Rata-rata & SB & \\
\hline Jenis kelamin & & & & & & & $\left.0,013^{*}\right)$ \\
\hline Laki-laki & $59(93,7)$ & & & $4(6,3)$ & & & \\
\hline Perempuan & $52(78,8)$ & & & $14(21,2)$ & & & \\
\hline Usia (tahun) & & 70,78 & 5,04 & & 69,72 & 4,38 & $\left.0,375^{* *}\right)$ \\
\hline Indeks massa tubuh $\left(\mathrm{kg} / \mathrm{m}^{2}\right)$ & & 22,49 & 1,57 & & 23,24 & 1,94 & $\left.0,161^{* *}\right)$ \\
\hline Lama operasi (menit) & & 208,74 & 85,07 & & 145,28 & 42,58 & $\left.0,002^{* *}\right)$ \\
\hline Suhu ruang operasi $\left({ }^{\circ} \mathrm{C}\right)$ & & 23,77 & 0,65 & & 23,55 & 0,51 & $\left.0,182^{* *}\right)$ \\
\hline Lama puasa (jam) & & 8,85 & 2,09 & & 8,50 & 2,06 & $\left.0,526^{* *}\right)$ \\
\hline
\end{tabular}

Keterangan: *)dihitung menggunakan uji chi-kuadrat, ${ }^{* *}$ ) dihitung menggunakan UJi Mann Whitney 
Tabel 4 Hubungan Jenis Operasi dan Jenis Anestesi dengan Kejadian Hipotermia di Ruang Pemulihan

\begin{tabular}{|c|c|c|c|c|c|c|c|}
\hline \multirow{3}{*}{ Variabel } & \multirow{2}{*}{\multicolumn{2}{|c|}{ Total Pasien }} & \multicolumn{4}{|c|}{ Kejadian Hipotermia } & \multirow{3}{*}{ Nilai p } \\
\hline & & & \multicolumn{2}{|c|}{ Ya } & \multicolumn{2}{|c|}{ Tidak } & \\
\hline & $\mathbf{n}$ & $\%$ & $\mathbf{n}$ & $\%$ & $\mathbf{n}$ & $\%$ & \\
\hline Jenis operasi & & & & & & & $\left.0,049^{*}\right)$ \\
\hline Abdomen & 47 & 36,4 & 44 & 93,6 & 3 & 6,4 & \\
\hline Nonabdomen & 82 & 63,6 & 67 & 81,7 & 15 & 18,3 & \\
\hline Jenis anestesi & & & & & & & $\left.<0,001^{*}\right)$ \\
\hline Umum & 90 & 69,8 & 86 & 95,6 & 4 & 4,4 & \\
\hline Regional epidural & 25 & 19,4 & 12 & 48,0 & 13 & 52,0 & \\
\hline Regional spinal & 4 & 3,1 & 3 & 75,0 & 1 & 25,0 & \\
\hline CEGA & 10 & 7,8 & 10 & 100,0 & 0 & 0,0 & \\
\hline
\end{tabular}

Keterangan: dihitung dengan menggunakan *) uji chi-kuadrat

dengan kejadian hipotermia ( $p \leq 0,05$; Tabel 3$)$.

Pada penelitian ini tidak terdapat hubungan bermakna antara usia dan kejadian hipotermia ( $p>0,05)$. Indeks massa tubuh pada penelitian ini berdasarkan pada hasil uji statistika tidak menggambarkan hubungan yang bermakna dengan angka kejadian hipotermia ( $p>0,05)$. Temperatur kamar operasi juga tidak terdapat hubungan bermakna dengan angka kejadian hipotermia $(p>0,05)$. Berdasarkan pada hasil uji statistika, menunjukkan tidak terdapat

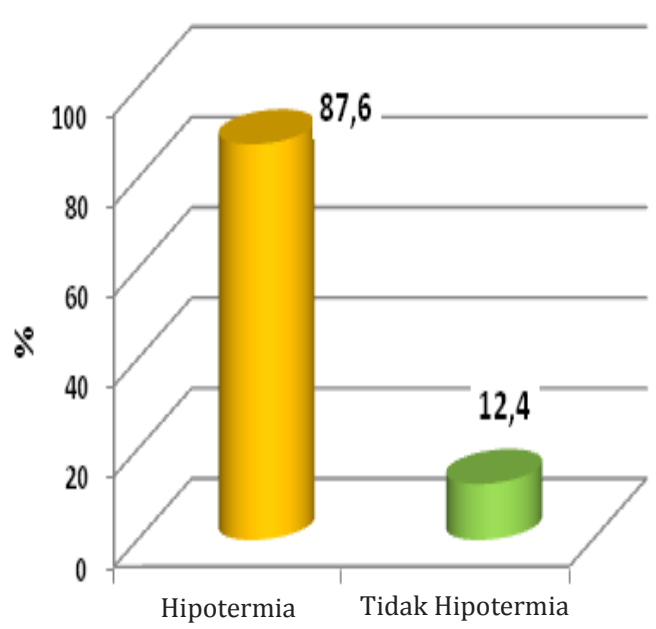

Gambar 1 Kejadian Hipotermia di Ruang Pemulihan hubungan yang bermakna antara lama puasa dan kejadian hipotermia ( $p>0,05$; Tabel 3 ).

Pembedahan di daerah abdomen dilakukan pada 47 orang pasien $(36,4 \%)$ dengan jumlah pasien yang mengalami hipotermia sebanyak 44 orang $(93,6 \%)$. Pada pembedahan nonabdomen, terdapat 82 orang $(63,6 \%)$ dengan jumlah pasien yang mengalami hipotermia adalah sebanyak 67 orang $(81,7 \%)$. Sebagian besar dari subjek penelitian tersebut dilakukan tindakan operasi dalam anestesi umum, yaitu

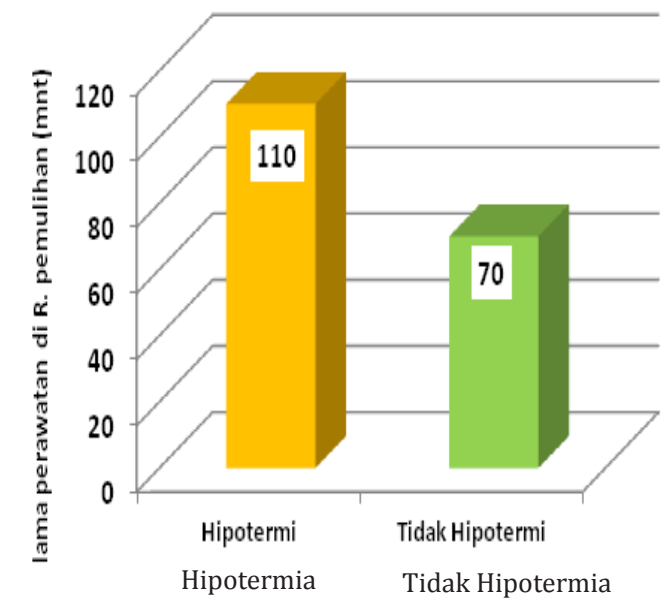

Gambar 2 Hubungan Kejadian Hipotermia dengan Lama Perawatan di Ruang Pemulihan pada Pasien Geriatri 
Tabel 5 Hubungan Kejadian Hipotermia dengan Lama Perawatan di Ruang Pemulihan

\begin{tabular}{lccc}
\hline \multirow{2}{*}{$\begin{array}{c}\text { Kejadian } \\
\text { Hipotermia }\end{array}$} & \multicolumn{2}{c}{ Lama Perawatan (menit) } & \multirow{2}{*}{ Nilai p } \\
\cline { 2 - 3 } & Rata-rata (SD) & Median & $<\mathbf{0 , 0 0 1}^{* *}$ ) \\
Ya & $113,63(23,94)$ & 110 & \\
Tidak & $75,63(14,12)$ & 70 & \\
\hline
\end{tabular}

Keterangan : **)dihitung dengan menggunakan Uji Mann-Whitney

sebanyak 90 orang $(69,8 \%)$ dengan kejadian hipotermia pada 86 orang $(95,6 \%)$. Kejadian hipotermia pada pasien yang mendapatkan tindakan anestesia epidural sebanyak 12 dari 25 orang, pada anestesia spinal 3 dari 4 orang dan semuanya pada kombinasi anestesi umum dan epidural (Tabel 4).

Hasil uji statistika dengan menggunakan uji chi-kuadrat pada uji kepercayaan 95\% terdapat hubungan yang bermakna antara jenis operasi dan kejadian hipotermia $(\mathrm{p} \leq 0,05)$. Hubungan bemakna juga terdapat antara jenis anestesi dan kejadian hipotermia ( $\mathrm{p} \leq 0,05$; Tabel 4).

Pada penelitian ini pasien yang mengalami hipotermia mendapatkan perawatan di ruang pemulihan yang lebih lama bila dibandingkan dengan pasien yang tidak hipotermia $(113,6$ vs 75,6 menit). Berdasarkan hasil uji statistik dengan mempergunakan Uji Mann Whitney pada uji kepercayaan 95\% terdapat hubungan yang bermakna antara kejadian hipotermia dan lama perawatan di ruang pemulihan pada pasien geriatri $(p \leq 0,05$; Tabel 5$)$.

\section{Pembahasan}

Pada penelitian ini didapatkan angka kejadian hipotermia di ruang pemulihan pada pasien geriatri yang telah menjalani operasi elektif di Rumah Sakit Dr. Hasan Sadikin Bandung pada bulan Oktober 2011 sampai dengan Maret 2012 sebanyak 113 orang $(87,6 \%)$. Angka ini lebih tinggi dibandingkan dengan angka kejadian hipotermia pada hasil penelitian yanglain, yaitu sebesar $50-70 \%{ }^{1,2}$ Pada penelitian ini, lebih dari $80 \%$ operasi dilakukan mempergunakan teknik anestesia umum dibandingkan dengan anestesia regional. Tindakan anestesi umum dapat menghilangkan proses adaptasi serta mengganggu mekanisme fisiologi pada fungsi termoregulasi. ${ }^{1}$

Anestesia umum juga memengaruhi ketiga elemen termoregulasi yang terdiri atas elemen input aferen, pengaturan sinyal di daerah pusat dan juga respons eferen, serta menggeser batas ambang untuk respons proses vasokonstriksi, menggigil, vasodilatasi, dan juga berkeringat. Selama anestesia, terutama anestesia umum, ambang termoregulasi menjadi lebih rendah pada pasien geriatri bila dibandingkan dengan pasien yang berusia muda, yaitu sekitar $1{ }^{\circ} \mathrm{C}$. Sebagai konsekuensi, maka suhu tubuh pasien selama pembedahan menjadi poikilotermik, yaitu akan mengikuti suhu lingkungan. Hampir semua jenis obat-obat anestesia mengganggu respons termoregulasi, misalnya penggunaan obat anestesia inhalasi yang akan menurunkan ambang vasokonstriksi dan menggigil.

Semua obat anestesia umum memengaruhi termoregulasi dengan tingkatan yang hampir sama. Penggunaan fentanil sebagai analgesia intraoperatif dapat menurunkan suhu tubuh pascaoperasi rata-rata sebesar $0,8{ }^{\circ} \mathrm{C}$. Fentanil diduga mempunyai efek blokade panas yang dihasilkan oleh proses metabolisme, sehingga terjadi penurunan suhu pascaoperasi. Propofol akan menurunkan ambang vasokonstriksi dan pengeluaran keringat. Suatu penelitian yang membandingkan induksi antara sevofluran dan propofol didapatkan hasil bahwa induksi propofol menyebabkan penurunan suhu lebih besar. $^{1,16}$

Hipotermia perioperatif akan memengaruhi metabolisme berbagai obat-obatan anestesia yang disebabkan enzim-enzim yang mengatur fungsi organ dan juga durasi obat yang sangat 
sensitif terhadap perubahan suhu. Hipotermia ringandapatmenggangguprofilfarmakokinetik propofol dan juga meningkatkan durasi kerja atrakurium, vekuronium, serta pankuronium Kadar propofol plasma akan meningkat 30\% pada saat penurunan suhu inti $3{ }^{\circ} \mathrm{C}$ di bawah normal. Hipotermia juga akan memengaruhi farmakodinamik obat anestesia inhalasi.

Kelarutan obat anestesia inhalasi di dalam plasma akan meningkat, sehingga saat dalam keadaan equilibrium, obat yang terdistribusi di dalam tubuh akan lebih banyak. Peningkatan kelarutananestesiainhalasiserta pemanjangan durasi kerja pelemas otot diduga merupakan penyebab lambatnya pasien bangun pada saat akhir anestesia. Masa perawatan saat di ruang pemulihan rata-rata menjadi bertambah pada pasien hipotermia. ${ }^{1,16}$

Pada hasil penelitian ini terdapat hubungan yang bermakna antara hipotermia dan lama perawatan di ruang pemulihan pada pasien geriatri yang telah menjalani operasi elektif di Rumah Sakit Dr. Hasan Sadikin Bandung, dengan lama perawatan rata-rata pada pasien hipotermia 110 menit dibandingkan dengan pasien yang tidak hipotermia, yaitu 70 menit $(\mathrm{p} \leq 0,05)$.

Ketiga elemen termoregulasi yang meliputi input aferen, pengaturan sinyal di pusat serta respons eferen, dapat dipengaruhi semuanya oleh anestesia. Anestesia umum memengaruhi ketiga elemen tersebut, sedangkan anestesia regional hanya akan berpengaruh pada 2 (dua) komponen, yaitu input aferen dan juga respons eferen. Epidural serta spinal dapat menggeser ambang vasokonstriksi serta menggigil, namun dengan derajat di bawah anestesi umum. Hal yang menarik apabila terjadi core hipothermia pada saat anestesia regional yang mungkin saja tidak mencetuskan perasaan dingin terhadap pasien. Persepsi dingin bergantung pada input aferen yang sudah terganggu akibat blokade saraf. Perubahan suhu pada usia geriatri akan terjadi lebih lambat. Geriatri juga lebih rentan terhadap hipotermia. Pada pasien tua, terjadi kegagalan termoregulasi relatif dibandingkan dengan pasien lebih muda. Pada geriatri telah terjadi kegagalan memelihara suhu tubuh, baik dengan atau tanpa anestesi, kemungkinan hal ini terjadi karena penurunan vasokonstriksi termoregulasi yang terkait dengan usia. ${ }^{1,2,17,18}$

Pada penelitian ini terdapat hubungan yang bermakna antara jenis anestesia dan kejadian hipotermia saat pascaoperasi $(p \leq 0,05)$. Selama penelitian ini dilaksanakan, tidak ditemukan komplikasi hipotermia atau efek samping yang serius.

Jenis operasi besar yang membuka rongga tubuh, misal pada operasi rongga toraks atau abdomen, akan sangat berpengaruh terhadap angka kejadian hipotermia. Operasi abdomen dikenal sebagai penyebab hipotermia karena berhubungan dengan operasiyang berlangsung lama, insisi yang luas, dan sering membutuhkan cairan guna membersihkan ruang peritoneum. Keadaan ini mengakibatkan kehilangan panas yang terjadi ketika permukaan tubuh pasien yang basah serta lembab, seperti perut yang terbuka dan juga luasnya paparan permukaan kulit. Evaporasi adalah proses perubahan sifat fisika dari bentuk zat cair ke dalam bentuk gas, disertai pelepasan sejumlah panas sebanyak 20-27\%. ${ }^{1,2}$ Pada hasil penelitian ini, terdapat hubungan yang bermakna antara jenis operasi dan kejadian hipotermia $(p \leq 0,05)$.

Satu jam pertama pascainduksi akan terjadi redistribusi panas tubuh dari daerah inti tubuh ke perifer sehingga terjadi penurunan suhu inti tubuh 1 sampai $1,5{ }^{\circ} \mathrm{C}$. Setelah itu, penurunan suhu inti berlangsung lebih lambat, kondisi ini diakibatkan oleh proses kehilangan panas yang melampaui daya produksi oleh tubuh. Setelah 3 sampai 5 jam akan terjadi kesetimbangan antara proses kehilangan dan pembentukan panas, sehingga suhu menjadi stabil. Induksi anestesi mengakibatkan vasodilatasi sehingga 46 kkal panas tubuh didistribusikan selama 1 jam pertama, dengan tambahan 17 kkal akibat redistribusi panas dari inti tubuh ke jaringan perifer dalam waktu 2 jam., ${ }^{3,4}$

Suhu tubuh manusia akan bergantung pada neraca keseimbangan panas yang diproduksi ataupun diabsorbsi dengan panas yang hilang. Panas diproduksi secara terus menerus oleh tubuh sebagai hasil dari metabolisme. Proses kehilangan panas tubuh terjadi secara terus menerus. Proses produksi serta pengeluaran panas diatur oleh tubuh guna mempertahankan 
suhu inti tubuh dalam rentang $36-37,5^{\circ} \mathrm{C}$. Pada penelitian ini terdapat hubungan bermakna antara lama operasi dan kejadian hipotermia di ruang pemulihan $(p \leq 0,05)$.

Suhu kamar operasi selalu dipertahankan 20-24 ${ }^{\circ} \mathrm{C}$ untuk meminimalkan pertumbuhan bakteri. Paparan suhu ruangan operasi yang rendah dapat mengakibatkan pasien menjadi hipotermia ringan sampai sedang akibat dari proses radiasi.

Radiasi adalah gelombang elektromagnetik yang ditransmisikan oleh tubuh tanpa melalui medium perambatan, serta merupakan hasil akhir selisih antara suhu permukaan kulit dan suhu lingkungan. Proses ini merupakan 60\% dari seluruh mekanisme terjadinya kehilangan suhu. Tindakan anestesia serta pembedahan dapat mengakibatkan gangguan keseimbangan normal antara produksi dan kehilangan panas. Obat anestesi, opioid, dan obat penenang akan menghambat respons perilaku serta respons autonom, sehingga akan menyebabkan pasien menjadi poikilotermik. ${ }^{4,19}$

Tidak terdapat hubungan bermakna antara suhu kamar operasi dan kejadian hipotermia pada penelitian ini. Keadaan ini karena suhu ruangan pada penelitian ini diatur pada suhu $\geq 23{ }^{\circ} \mathrm{C}$. Temperatur kamar disesuaikan melalui pelepasan panas tubuh pasien dengan cara radiasi serta konveksi dan selalu berada pada temperatur $>23{ }^{\circ} \mathrm{C}$ untuk menjaga suhu dalam batas normotermia.

Tindakanpenghangatanakanmeningkatkan suhu tubuh rata-rata dengan meningkatkan kandungan energi pada kompartemen suhu perifer tubuh. Hal ini penting karena sulit sekali untuk mengatasi penurunan suhu tubuh yang disertai vasodilatasi akibat tindakan anestesi umum dan regional sehingga panas berpindah dari inti tubuh ke perifer secara cepat. Secara tradisional, perawat mempergunakan selimut penghangat untuk meningkatkan suhu tubuh pada pasien pascaoperasi di ruang pemulihan. Pada suhu ruangan $26{ }^{\circ} \mathrm{C}$ atau lebih terbukti dapat menurunkan insidensi hipotermia pada pasien muda maupun tua. Untuk mencegah hipotermia, maka keseimbangan bobot panas tubuh harus terjaga melalui keseimbangan antara pengeluaran panas dan produksi, baik melalui proses metabolisme tubuh sendiri atau sumber panas yang berasal dari lingkungan eksternal. ${ }^{3,11,13}$ Terdapat hubungan bermakna antara intervensi yang dilakukan dan lamanya perawatan di ruang pemulihan.

\section{Simpulan}

Angka kejadian hipotermia di ruang pemulihan pada pasien geriatri yang menjalani operasi elektif di Rumah Sakit Dr. Hasan Sadikin Bandung adalah sebanyak 87,6\%. Kejadian hipotermia menyebabkan lama perawatan di ruang pemulihan meningkat.

\section{Daftar Pustaka}

1. Buggy DJ, Crossley AW. Thermoregulation, mild perioperative hypothermia and post anaesthetic shivering. Br J Anaesth 2000;84(5):615-28.

2. Bush HL, Jr., Hydo LJ, Fischer E, Fantini GA, Silane MF, Barie PS. Hypothermia during elective abdominal aortic aneurysm repair: the high price of avoidable morbidity. J Vasc Surg. 1995;21(3):392-400.

3. Frank SM, Shir Y, Raja SN, Fleisher LA, Beattie C. Core temperature and skinsurface temaperature gradients: epidural vs general anesthesia and the effects of age. Anesthesiology. 1994;80:502-8.

4. Putzu M, Casati A. Clinical complications, monitoring and management of perioperative mild hypothermia: anesthesiological features. Acta Biomed. 2007;78:163-9.

5. Joshi M, Shivkumaran S, Bhargava V, Kansara B, Sharma RS. Perioperative management of the geriatric patient. J Indian Academy of Geriatrics. 2006;2:2833.

6. Bergman SA, Coletti D. Perioperative management of the geriatric patient. Part II: cardiovascular system. Oral Surg Oral Med Oral Pathol Oral Radiol Endod. 2006;102(3):e7-12.

7. Keilson L, Lambert D, Fabian D, Thebarge J, Ackerson T, Palomaki G, dkk. Screening 
for hypothermia in the ambulatory elderly. JAMA. 1995;254:1781-4.

8. Kumra VP. Issues in geriatric anesthesia. SAARC J Anesthesia. 2008;1:39-49.

9. Morgan GE,Mikhail MS, Murray MJ.Geriatric anesthesia. Clinical anesthesiology. Edisi ke-4. USA: Lange Medical Book McGrawHill; 2006.

10. Tappen RM, Andre SP. Inadvertent hypothermia in elderly surgical patients. AORN J. 1996;63(3):639-44.

11. Ihn CH, Joo JD, Chung HS, Choi JW, Kim DW, Jeon YS, dkk. Comparison of three warming devices for the prevention of core hypothermia and post-anaesthesia shivering. J Int Med Res. 2008;36(5):92331.

12. Anonymous. Prevention of inadvertent perioperative hypothermia. Pennsylvania Patient Safety Advisory. 2008;5:44-51.

13. Macario A, Dexter F. What are the most importan risk factors for a patients developing intraoperative hypothermia. Anesth Analg. 2002;94:215-20.
14. Anonymous. Data Instalasi Bedah Sentral. Bandung: Rumah Sakit Dr. Hasan Sadikin; 2010.

15. Stoelting RK, Hillier SC, penyunting. Pharmacology and physiology in anesthetic practice. Edisi ke-4. Philadelphia: William and Wilkins; 2006.

16. Sessler DI.Perianesthetic thermoregulation and heat balance in humans. FASEB J. 1993;7(8):638-44.

17. Dicker A, Ohlson K, Johnson L, Canon B, Lindahl S, Nedergaard J. Halothan selectively inhibits non shivering thermogenesis Anesthesiology. 1995; 82:491-501.

18. Kiekkas P, Poulopoulou M, Papahatzi A, Souleles P. Effects of hypothermia and shivering on standard PACU monitoring of patients. AANA J. 2005;73(1):47-53.

19. Roger $H$, Morris MD. Operating room temperature and the anesthetized, paralyzed patient. Review article Anesthesiology. 1971;102:95-7. 